\title{
10
}

\section{THE COVID-19 PANDEMIC AND HUNGARIAN HUMAN RESOURCES: CHALLENGES AND RESPONSES}

\author{
József Poór, Krisztina Dajnoki, Ildikó Éva Kovács, Arnold Tóth, and Botond Kálmán
}

\begin{abstract}
In Hungary, the first phase of the nationwide research project was conducted between May and August 2020. Their first research report was published on 1 October 2020. The purpose of this study is to answer the following question: What challenges and changes have the Coronavirus crisis caused in domestic Human Resource Management? This research was carried out by 13 Hungarian and one Slovakian university. Regional chambers of commerce and HEIs supported the research project. Data collection took place from 12 June to 31 July 2019. They collected data from 508 Hungarian organizations (companies and public bodies) using an online questionnaire and analyzed them with the application of different statistical methodologies. Currently, the research is in its second phase, involving studying the subject in Hungary and neighbouring countries, using questionnaires suitably adapted to the given language and economic specifications. Additionally, the publication of partial research results commenced in periodicals related to the field. This extensive work encouraged the authors of the present study to write the following book chapter.
\end{abstract}

KEYWORDS

COVID-19, human resource management, Hungary

J. Poór

J. Selye University, Slovakia

E-mail: poorj@ujs.sk

\section{K. Dajnoki}

University of Debrecen, Hungary

E-mail: dajnoki.krisztina@econ.unideb.hu

\section{I. É. Kovács}

Hungarian Agrar and Life Sciences University, Hungary

E-mail: Kovacs.Ildiko.Eva@szie.hu

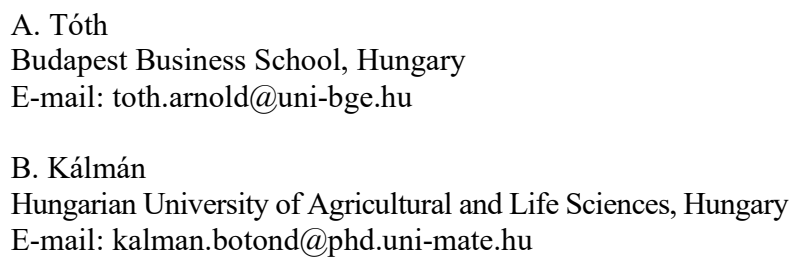




\section{Introduction - The COVID-19 and the Human Resource Management}

The COVID-19 pandemic beginning in China at the end of 2019 has been the fastest emerging and spreading pandemic in history. The ten months that have passed so far have led to 54.7 illnesses, and the death toll presently at 1,3 million. Today, the United States, India, and Brazil have the highest number of infected people, but France is the most heavily infected among the European nations. Regarding the number of cases per one million people, Hungary is 57th among the world's nations. There is not yet an effective, safe, and mass-available vaccine, the only means of prevention are social distancing, wearing masks, and regular handwashing, as well as isolating those who are infected and the legal regulation of free movement (lockdown measures, curfews). These measures affect us all. Many employers suspended operations or permanently closed down; this led to an increase in unemployment and threatened many families' financial safety. Based on the concept of a good state, good governance, the government and employers have an essential role in solving the challenges that have arisen due to the pandemic. The role of Human Resource Management (HRM) has become especially significant. The professionals working in this area have the skills and opportunities to provide valuable assistance in solving these problems in every dimension, from implementing general measures to personal problem-solving.

\section{Objectives - Hungary, HRM and COVID-19}

This chapter aims to present the reader with Hungary, the pandemic's effects on the country, and the government, employers, and HR experts' measures to ease the economy's burdens and the people. The authors wish to present within these limits the challenges posed by the pandemic and the results of the responses to these.

In order to place HR activity in Hungary during the COVID epidemic into a broader framework, we introduce Hungary's social-economic characteristics, briefly mentioning historical aspects as well. We outline the economic development trajectory that the country has undergone since the collapse of the state-socialist system. We show the creation of the development's foundations, the effects of the 2008 recession on the Hungarian economy, and the course of normalization and the development that followed. We partially compare the country's achievements to its surrounding region, the European Union but in many aspects, we also use data regarding India as reference to illustrate that COVID 19 is a global phenomenon and that we may choose from a multitude of alternatives when responding to this pandemic. After this, we describe Hungarian HR's short history and perspectives, separately focusing on the profession's tasks during the COVID-19 pandemic. We furthermore present the pandemic's phases in Hungary as well as their characteristics.

\subsubsection{Socio-economic overview}

Hungary is located in Central Europe; it is $93,000 \mathrm{~km}^{2}$, its population is 9.6 million. Furthermore, a significant number of Hungarians live in neighbouring countries. In the twentieth century, the country's history was determined mainly by being a part of the Soviet scope of interest and by socialism (Berend, 1999). There were three variants of socialism, market driven planning system was introduced in Hungary in 1968 (Wolf \& Poór, 1990) After the fall of the Soviet Union and due to the Hungarian regime change, the country could embark on a path of development. But this transformation was not easy, with changes at the time leading to high inflation and a drastic decrease in output performance during the 1990s (Poór et al., 2018). Our country has been a member of the OECD since 1996 and a European Union member state since 2004. The authors will present the country's cultural characteristics and its people based on the internationally accepted research results 
of Gerd Hofstede (Hofstede et al., 2010). The model is based on the definition of culture, which is the collective mental programming of the human mind that distinguishes one group of people from another. Of course, this does not imply that everyone in a given society is programmed in the same way. This classification characterizes a given country's residents based on six dimensions, and these are compiled in Table 1. In the table, we compare Hungary to India.

Table 1.

Cultural dimensions of India and Hungary (Source: Hofstede, 2010 - edited by the author)

\begin{tabular}{|c|c|c|c|}
\hline Name of dimension & Meaning of the value & India & Hungary \\
\hline $\begin{array}{l}\text { Power distance index } \\
\qquad(\mathrm{PDI})\end{array}$ & $\begin{array}{c}\text { A higher degree indicates that hierarchy is clearly established } \\
\text { and executed in society }\end{array}$ & 77 & 46 \\
\hline $\begin{array}{l}\text { Individualism vs. } \\
\text { collectivism (IDV) }\end{array}$ & $\begin{array}{c}\text { This index explores the degree to which people in a society } \\
\text { are integrated into groups }\end{array}$ & 48 & 80 \\
\hline $\begin{array}{l}\text { Individualism vs. } \\
\text { collectivism (IDV) }\end{array}$ & $\begin{array}{c}\text { A lower degree in this index shows more acceptance of } \\
\text { differing thoughts or ideas }\end{array}$ & 56 & 80 \\
\hline $\begin{array}{l}\text { Masculinity vs. femininity } \\
\text { (MAS) }\end{array}$ & $\begin{array}{l}\text { Higher degree indicates higher preferences of heroism, } \\
\text { assertiveness and material rewards for success }\end{array}$ & 40 & 82 \\
\hline $\begin{array}{l}\text { Long-term vs. short-term } \\
\text { orientation (LTO) }\end{array}$ & $\begin{array}{l}\text { A lower degree of this index (short-term) indicates that } \\
\text { traditions are honoured and kept }\end{array}$ & 51 & 58 \\
\hline $\begin{array}{l}\text { Indulgence vs. restraint } \\
\text { (IND) }\end{array}$ & $\begin{array}{l}\text { A higher degree indicates a society that controls gratification } \\
\text { of needs and regulates it by means of strict social norms }\end{array}$ & 26 & 31 \\
\hline
\end{tabular}

Based on the table above, it can be said that Hungarian culture is very individualistic and explicitly masculine; success is measured in performance and power. A competitive attitude and settling conflicts via struggle are characteristic of our culture. Hungarian people do not like uncertainty; they require rules, which they often break (Jarjabka, 2014). In this culture, hard work is valued, and time is money. Frugality and perseverance are seen as values. However, people are prone to pessimism. In India, there is a high level of respect for hierarchy and top-down communication. Indian society is intermediately individualistic, and the opinions of one's environment significantly influence actions. The intermediate rating can be explained by the almost congruent levels of individualism and collectivism, which is realized through Westernization and Hinduism's joint prevalence. This duality is apparent in the joint presence of power and success orientation and spiritualism. The Indian people are traditionally patient and accept imperfection. However, they can innovatively bridge the limitations posed by rules; thus, in India, nothing is impossible. Indian time is not linear, and rebirth always means new possibilities. Thus, time and its passing are less significant to people, and they are able to modify predetermined plans flexibly.

In the early 1990s, Hungary was faced with a severe economic downturn, high unemployment rates as well as financial-economic measures responding to these situations. The transformation of the economy caused a great deal of difficulty: the implementation of market conditions led to a decline in the GDP, unemployment, an unknown concept until then, became a mass problem, and the inflation rate rose high. However, this decline stopped in 1994, the GDP began to increase even though it came at the cost of a disturbance in the economic balance. The country's economy began to slowly stabilize thanks to the Bokros Austerity Package, which contained elements that had caused outrage during the Horn administration and the income generated by the privatization of state assets: growth became permanent. The country has escaped state bankruptcy (Szegö, 2015). Like other countries in the 
region, foreign capital played a significant role in privatization in Hungary ases of other $\mathrm{CEE}^{2}$ countries (Lewis (2005), as some Western politicians refused to create a new Marshall Plan.Many were hoping for a New Marhal Plan at the time, but its implementation was left to multinational companies by Wester n governments (Bod, 2015). The development of the transportation network, the business-friendly environment of the industrial parks constructed around cities, as well as the improving economic indices, increased confidence on the part of foreign investors, and thus, the influx of capital. Joining the European Union led to an influx of billions of euros, which played a defining role in the country's infrastructural development. The constitution defines the Hungarian economy. The Fundamental Law lays down the principles of fair competition and social market economy. The economy is foremost regulated by the proportion of supply and demand, supplemented by state regulations (taxes, anti-inflation policy). The annual growth of GDP per person is at a steady incline, just like in India (Figure 1). Due to the favorable location of the country, its skilled workforce and its developed transport infrastructure, nearly $\$ 100$ billion in foreign capital was received between 1989 and 2017 (Investment, 2019). Prior to the COVID-19 pandemic, the largest exports were made by three car factories operating in the country (AUDI, Mercedes, Suzuki).

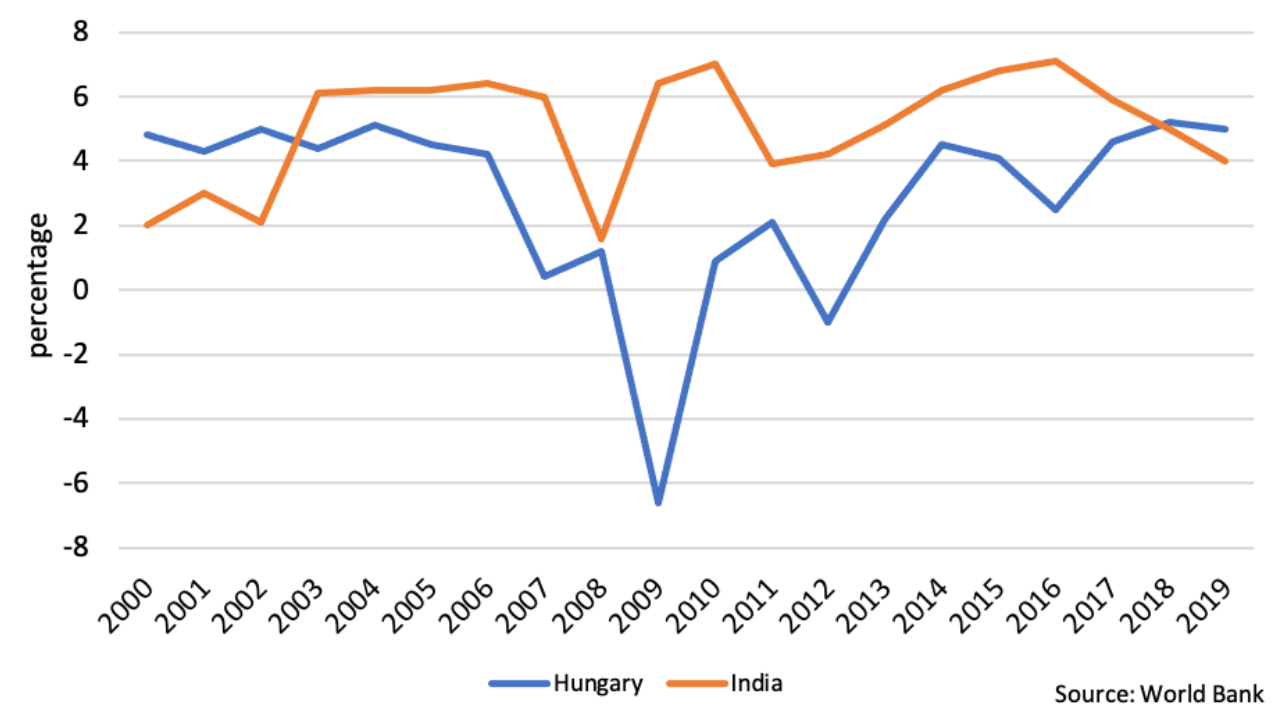

Figure 1. GDP per capita growth (annual \%)

The 2008 economic depression affected Hungary as well. After the steep decline the GDP experienced in 2009, national bankruptcy was only prevented by quick and effective assistance from the IMF (Carara, 2009) and the European Union. The second Orbán administration, governing the country since 2010, has implemented changes to the economic policies of the previous governments. They provided assistance to those with foreign currency loans in a crisis sitssonuation due to the rapid increase of the Swiss franc's exchange rate, paid the IMF debt, and converted to the state debt's internal financing. The budget deficit has complied with the Maastricht criteria for years now, smaller than $3 \%$ of the GDP. The planned budget deficit for 2020 was $1 \%$ of the GDP, apart from which the budget act ensured the same amount of reserve. Salaries in Hungary are low compared with the rest of the European Union, but the rate of unemployment is similarly low as in other EU member CEE countries (Error! Reference source not found.). This is primarily also due to the government's public employment program.

${ }^{2} \mathrm{CEE}=\mathrm{Central}$ and Eastern European countries 


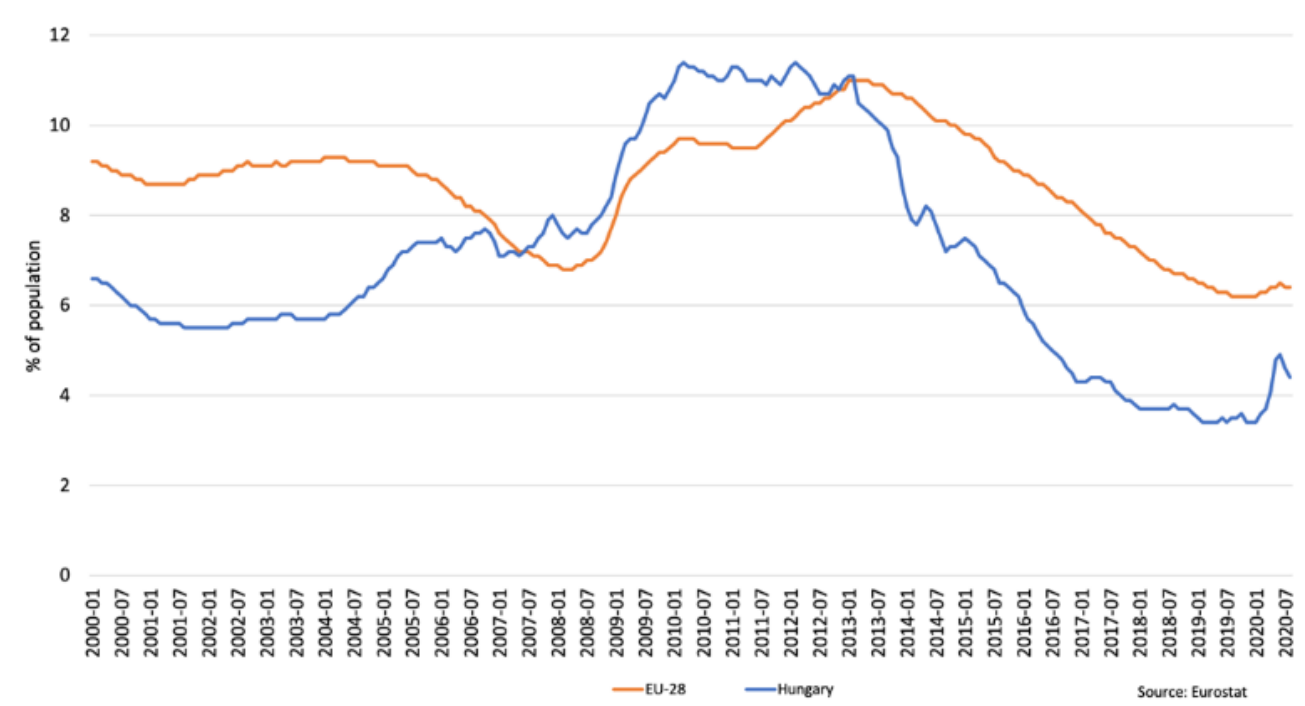

Figure 2. Unemployment in Hungary and in EU (2000-2020)

When examining the temporal trend, the unemployment situation in Hungary is positive. After 2010 the employment situation has step by step changed. As a result, between 2010 and 2015, according to Eurostat, employment increased by 9.0 percentage points to $63.9 \%$ (KSH, 2020). In accordance with the modern marketability approach, the increasingly capital-intensive sectors are developing; these characteristically offer higher-qualified individuals with stable income and livelihoods. Similarly, to developed industrial countries, Hungary also has an increasingly elderly population, and the population carrying out high-value work is supporting many inactive individuals (students, pensioners, the unemployed.) The GDP-proportional national budget in Hungary is at $-2.1 \%$, a deficit worse than the EU average, but it has been well above the 3\% Maastricht criteria for years. The state debt is about $70,9 \%$ of the annual gross national product (Figure 3 ). The value of the labour market tightness indicator (the number of vacant posts) in early 2020 is $2 \%$ in the European Union; it is the highest in the Czechia (4,1\%), while in Hungary it is 1,9\% (Eurostat 2020)

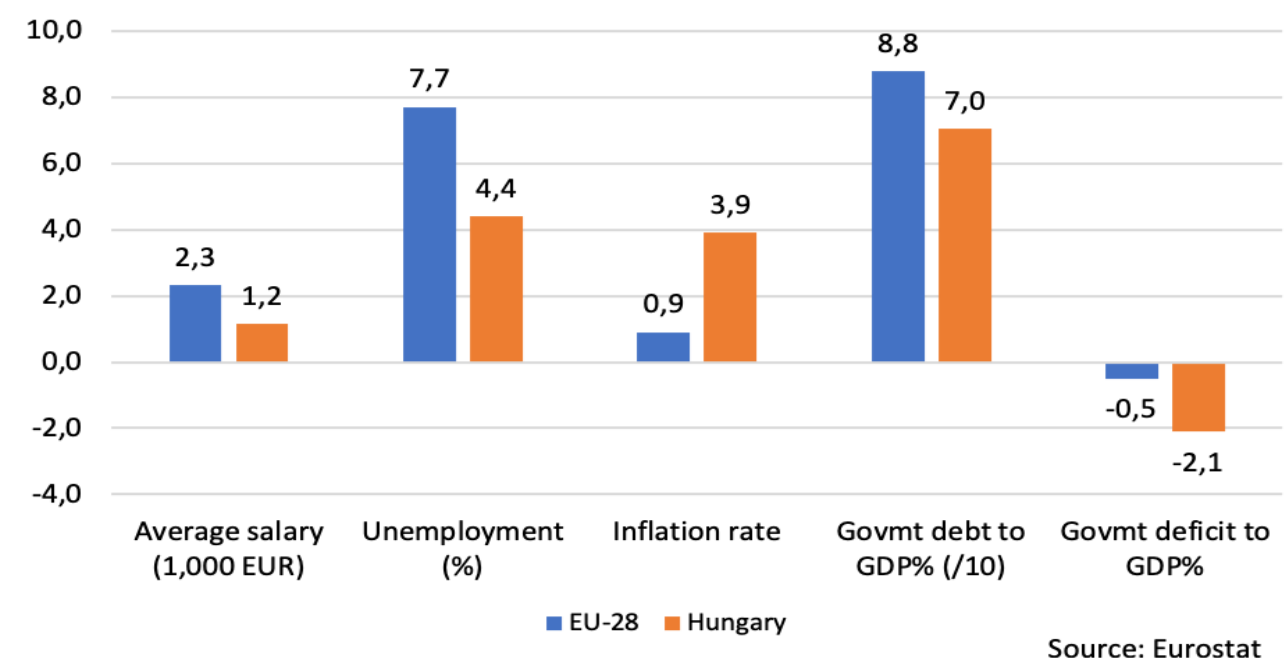

Figure 3. Hungarian Economy in European Union (2020)

The tendency was stopped by the pandemic, reaching the country in March 2020 and resulted in a forced suspension of much of the economy. 


\subsubsection{HRM in Hungary}

The history of HRM in Hungary is composed of a pre-1945, a socialist, and a subsequent transitional phase. This breakdown is the equivalent of the six phases of the classic Torrington \& Hall (1987) division, which we can briefly describe as follows:
1. reformer
2. secretary
3. bureaucrat
4. negotiator
5. organizational person
6. workforce analyzer

These six phases are at once a developmental process, that is, with each step forward, the previous step is supplemented with the following step, that is, in the sixth phase, all six functions are present in the HRM.

In the period before 1945, the first three of the six phases were carried out by copying western examples (Gulyás \& Turcsányi, 2017). The next three phases happened during the era of socialism, and due to the political determination, that permeated every aspect of life, these phases were significantly distorted. Apart from the definite effect of politics, the personnel history of this era was characterized by top-down leadership. The measure of successful personnel activities was the identification with external political and economic goals contrary to the modern market economy where organizational aims and micro-level rationality are the defining factors of suitability for a given task. As a result of being controlled from multiple aspects, the individual got lost in the personnel policy labyrinth. People could get ahead mainly through cadre policy, the main question regarding the evaluation of personnel was their political reliability. In the second half of the 1950s, this twodimensional HR practice changed (Karoliny\&Poór, 2019). The economic transformation leading to the emerging market socialism beginning in 1968 (Kornai, 1992) necessitated the emphasis of talent and aptitude apart from political loyalty; however, the personnel organization's separation was maintained.

From the middle of the 1980s, it became increasingly clear that the economic direction could not be sustained without real reforms. The emergence of business organizations from 1988 on led to the almost complete dissolution of the state personnel apparatus and this affected the talented and apt professionals who would have been much needed at those state-run companies. It was during this period that the concept of personnel policy was replaced by modern HR. However, in the initial years following the regime change, this was limited to a short-term, two-dimensionally administrative approach. The situation took a positive turn upon the influx of foreign working capital and multinational companies' settlement in Hungary. These companies brought up-to-date HR models that they had already been applying, thereby significantly restructuring Hungarian human-resource management culture. With these changes, HRM entered its seventh developmental phase, Torrington and Hall had not written about this yet, as their book would be published in 1987.

Poór and Roberson (2003) compiled the Hungarian characteristics and defining factors of HRM activities in the two-thousands which we have summarized in Table 2 below: 
Table 2 .

Characteristics and defining factors of Hungarian HRM activities (Source: Poór\&Roberson, 2003, edited by the authors)

\begin{tabular}{|c|c|}
\hline The characteristics of HRM & The determining factors of HRM \\
\hline private property & type of ownership \\
\hline increased competition & company size \\
\hline an improvement of economic performance & workplace culture \\
\hline integration into the global economy & Salaries \\
\hline a significant role of foreign property & brain drain \\
\hline EU membership & free labour movement \\
\hline
\end{tabular}

Naturally, the change did not come quickly or simply. Fifty years of socialist approach, customs, and business practices did not disappear from one day to the next. The efforts toward equality and affecting change in attitudes that included lacking respect for superiors, lower work morale, and eradicating the previous party system's effects took many years and a great deal of energy. Despite this, in the decade following the regime change, the new paradigm came fairly quickly. Dynamic change was experienced in the political, legal, social, and economic spheres. The investors who had been attentively analyzing historical realities and were the first to appear in Hungary were at a serious advantage compared to those later in the game. This was the case, for instance, with Japanese companies (Nádor, 1996), which had already entered the Hungarian market in years preceding the regime change, which has resulted in constant good relations between the two countries ever since. Their presence, their capital investments, and organizational culture did much to help Hungary overcome its socialist legacy. Several studies evaluate and analyze the development occurring in the twenty years after the regime changes in Central and Eastern Europe (Karoliny et al., 2009; Poór et al., 2011)

Hungary joined ongoing research into the area of human resources relatively early (Poór et al., 2011). The function of HRM, its significance, and efficacy can be measured well with certain indices. Labour cost to total cost ratio, the higher proportion, indicates that HR activities can contribute to company performance at a high rate. This ratio did not change from 2009-2018 (KSH, 2019), half of the total cost is composed of labour costs in both the state and the commercial sectors. The other index is the distribution of age groups among employees. This enables the efficacy of personnel-related work to be measurable, a good HR department can pay necessary attention to older employees as well. The literature considers over 45 to be the age limit of "redundancy" but not due to retirement. Hungarian HRM performs explicitly well in this area as this age group ratio has increased from $37 \%$ to $45 \%$ from 2009-2019 (KSH, 2020). Training cost to total cost ratio is an especially important indicator of the efficacy of HRM. From 2009 to 2018, this rose from 1,5\% to 2,1\%, which is a 1,4-fold increase. The tendency toward growth is somewhat negatively coloured by the fact that $3 \%$ has not yet been reached regarding the whole of the economy, however, it is positive that when taking into account the competitive sphere's ratios, twice as much was spent on training than in budget workplaces.

What are the future perspectives in the area of HRM? There are many authors with different views (Karoliny \& Poór, 2019). These, however, do not exclude one another, instead, they complement one 
another. The following challenges must be met: raising the professional standards of HR, increasing the HR knowledge of leadership, internationalization of HR activities, increasing the capacity for HR to provide added value, HR leadership and career opportunities in human resource management, and the increased competence of HR professionals. Further important international focus points are to increase corporate responsibility, maintain talent, and increase added value. The opinions held in the domestic sphere were surveyed in 2015 when Personal Hungary questioned 160 HR professionals (Nagy, 2015). Organizational development and training development were among the top concerns of domestic experts. The topics to tie for second place were change management and recruitmenthiring, whilst third was the issue of labour law. They mentioned the areas of health maintenance, IT, and safety as further essential factors.

The coronavirus pandemic modified the tasks of HRM to a large degree. Human resources managers are now responsible for assisting employees in their struggle with the stress due to restrictions, the smooth transition to the home office, and the work-life conflicts arising because of the experienced changes on an organizational level. The problems of employees being let go and company redundancy were even more significant problems. Many surveys were carried out on the possibilities HRM has for solving COVID-19 related issues. Among these were interviews conducted with experts to evaluate the opinions of those affected (Gigauri, 2020). According to the results, managing panic is the most crucial aspect, and this is best done by keeping employees and avoiding letting go of members of the workforce. Providing proper information in the new situation, online leadership, related technological knowledge, and crisis management strategies are all at the top of the list of concerns. New safety regulations that enable production to continue in the pandemic situation must be implemented as soon as possible. Other authors' (Caligiuri et al., 2020) research has yielded similar information: in a period of global stress and uncertainty, it is important, especially for multinational companies, to learn acceptance toward the different sensibilities, capacities, and reactions of employees from different cultures. It is vital to implement $24 / 7$ employee support systems, which provide healthcare, psychological, and safety counselling.

\subsubsection{COVID-19 in Hungary}

When viewing the history of the events and briefly summarising, the following can be said of the COVID-19 pandemic and how it has affected Hungary. Chinese authorities first reported the pandemic in December of 2019 (WHO - PLC, 2020). Despite the measures taken, the virus made its way out of China, and due to highly developed transportation networks, it took only a short time for it to appear in several parts of the world. The first epicentre in Europe was formed in Northern Italy in February 2020, where the disease continued to spread. The Prime Minister himself announced the first infected person in Hungary on March 4, 2020, the first death occurred on March 15. Three phases can be defined concerning the virus in Hungary. The first phase began with the arrival of news on the pandemic. On January 31, 2020, the government implemented the operative body responsible for protection against the coronavirus, the leaders of the Minister of the Interior and the Minister of Human Resources, who is also responsible for public health. In the beginning, the OB was engaged in the analysis of the situation after March 5th, however, their tasks expanded to the localization of infections, the implementation of epidemiological measures, as well as the coordination of the epidemiological measures of the different governmental organizations. On March 11, the Minister of the Prime Minister's Office announced the extraordinary legal order in the interest of slowing the spread of the disease and declared a state of emergency (Prime Minister's Office, 2020). The related regulations were published in issue 39 and 40 of the Hungarian Gazette on March 11 and 13, followed 
by several new measures. These were mainly toward the economy's suspension, the increased market inactivity, switching to online education in schools, and the restructuring of healthcare services. Thanks to the measures, the pandemic's spread began to slow at the beginning of May, and the first phase of the pandemic had come to an end. The economy, production, and the service sector resumed. The hospitality and tourism industries could breathe a sigh of relief as, during the summer, they were able to partially make up for the deficit accumulated during the spring months due to a large number of domestic tourists.

The spread of the pandemic slowed all the way until the second half of July. After this, the number of infected persons began to rise first slowly, then experienced a steep incline. By August, it was apparent that the second wave of the pandemic would begin. However, during this time (similarly to the majority of the world), no measures as strict as during the first wave were taken. Instead of being told to stay at home, people were mainly called on to wear masks in public spaces by various campaigns. On the first of September, "borders were closed" again, which meant that those entering the country from abroad had to be quarantined for two weeks, which was later changed to 10 days unless they were able to present two negative tests during this period. Schools and kindergartens operated normally, but if infected students were found in a class, the class would temporarily switch to online learning. A few schools had to shut down completely for a short time. By November, however, it was apparent that new, more stringent restrictions were necessary. Wearing a mask covering the nose and mouth became mandatory in a wider range of situations, from November 11th on, any form of public assembly was prohibited. Sports events could only be held without spectators, and amateur team sports were prohibited. Most stores can only be open until 7 PM. Restaurants cannot accept sit-in guests, they may only operate delivery services. Hotels can only host guests arriving for business and educational purposes, no tourists. People can only leave their homes between 8 PM and 5 AM with proper justification. Secondary schools and higher education have switched to online learning again, primary schools and preschools are still open to attendance.

\section{Our research}

\subsection{About Research}

In 2020, as discussed above, the COVID-19 pandemic had a significant effect on Hungary. The pandemic impacted all areas of everyday life as well as the economy, thus, HRM as well, which we are currently examining. A large-scale research project aimed at assessing the effects on this area called Coronavirus Crisis and HR Responses was initiated, this is a questionnaire-based research effort assessing the effects of the pandemic and the related restrictions on Hungarian companies, especially their HR organizations. Universities and scientific professional associations also take part in the research, among the supporting organizations there are county chambers of commerce, vocational training centres, and local governments. The detailed list is contained in Table 3.

The first phase of the research was carried out from June 15, 2020, to July 31, 2020, the report summarising the research results was published on October 1, 2020 (Poór et al., 2020). At present, the research is in its second phase with the participation of not only Hungarian universities and companies. The publication of the results so far has begun as well (Balogh et al., 2020). 
Table 3.

Research participants and supporters

\begin{tabular}{|c|c|}
\hline \multicolumn{2}{|c|}{ Research participants } \\
\hline Universities & Other organizations \\
\hline Budapest Metropolitan University (METU) & National Alliance of Humanities Professionals \\
\hline $\begin{array}{l}\text { Budapest Business School Faculty of Finance and } \\
\text { Accountancy (BGE) }\end{array}$ & National Human Management Association \\
\hline University of Debrecen (DE) & Hungarian Military Science Association \\
\hline \multicolumn{2}{|l|}{ Eötvös Loránd University (ELTE) } \\
\hline \multicolumn{2}{|l|}{$\begin{array}{l}\text { Hungarian Agrar and Life Sciences University } \\
\text { (MATE) }\end{array}$} \\
\hline \multicolumn{2}{|l|}{ Széchenyi István University (SZE) } \\
\hline \multicolumn{2}{|l|}{ University of Miskolc (ME) } \\
\hline \multicolumn{2}{|l|}{ National University of Public Service (NKE) } \\
\hline \multicolumn{2}{|l|}{ University of Pécs (PTE) } \\
\hline \multicolumn{2}{|l|}{ University of Sopron (SE) } \\
\hline \multicolumn{2}{|l|}{ University of Szeged (SZTE) } \\
\hline \multicolumn{2}{|l|}{ University of Kaposvár } \\
\hline \multicolumn{2}{|l|}{ University of Pannonia (PE) } \\
\hline \multicolumn{2}{|l|}{ János Selye University (UJS) } \\
\hline \multicolumn{2}{|c|}{ Supporters of the research } \\
\hline $\begin{array}{l}\text { Borsod-A-Z County Chamber of Commerce and } \\
\text { Industry }\end{array}$ & Frissdiplomás Kft \\
\hline Budapest Chamber of Commerce and Industry & $\begin{array}{l}\text { Local Government of Miskolc City with } \\
\text { County Rights }\end{array}$ \\
\hline $\begin{array}{l}\text { Csongrád County Chamber of Commerce and } \\
\text { Industry }\end{array}$ & Miskolc Vocational Training Center \\
\hline $\begin{array}{l}\text { Hajdú-Bihar County Chamber of Commerce and } \\
\text { Industry }\end{array}$ & \multirow{3}{*}{$\begin{array}{l}\text { Leader's Habits Research Network } \\
\text { - Humanagement - Human Value } \\
\text { international research group }\end{array}$} \\
\hline $\begin{array}{c}\text { Jász-Nagykun-Szolnok County Chamber of } \\
\text { Industry }\end{array}$ & \\
\hline Pécs-Baranya Chamber of Commerce and Industry & \\
\hline Somogy Chamber of Commerce and Industry & $\begin{array}{l}\text { Wolters Kluwer Co., Talk-A-Bot Co. and } \\
\text { Login Co. }\end{array}$ \\
\hline Vas County Chamber of Commerce and Industry & \\
\hline
\end{tabular}

(Source: Poór et al., 2020 - edited by authors)

\subsection{Methodology}

In the first phase of the research, 508 organizations (companies and public bodies) filled out the questionnaire. The respondents were categorized by the members of the research group in different ways: company size, ownership, annual revenue, geographical localization, and type of business activity. A fourth of respondents were foreign-owned. The participants were mainly micro, small, 
and midsize businesses. This is congruent because over $75 \%$ of Hungarian employees are working for these kinds of businesses. 99\% of Hungarian businesses are small to midsize, and these provide $55 \%$ of the GDP and $27,6 \%$ of export. The respondents represented a wide variety of sectors, as shown in Table 4.

Table 4

Economic activities of respondents (Source: Poór et al., 2020 - edited by authors)

\begin{tabular}{|c|c|c|}
\hline Activities of participants & NACE*-code & Per cent \\
\hline $\begin{array}{l}\text { Agriculture, forestry, fishing, } \\
\text { Mining and quarrying }\end{array}$ & $\begin{array}{l}\text { A, } \\
\text { B }\end{array}$ & $3.7 \%$ \\
\hline $\begin{array}{c}\text { Food and beverage } \\
\text { Textiles, wood, paper, petroleum products }\end{array}$ & $\begin{array}{c}\mathrm{C} 10, \mathrm{C} 11 \\
\mathrm{C} 13, \mathrm{C} 16, \mathrm{C} 17, \mathrm{C} 19\end{array}$ & $5.1 \%$ \\
\hline Chemical, pharmaceutical & $\mathrm{C} 20, \mathrm{C} 21$, & $1.4 \%$ \\
\hline Plastic, non-metallic products, metals & $\mathrm{C} 22, \mathrm{C} 23, \mathrm{C} 24$ & $3.7 \%$ \\
\hline Computer, electronic and optical products & $\mathrm{C} 26$ & $2.8 \%$ \\
\hline Machinery and equipment & $\mathrm{C} 28$ & $4.3 \%$ \\
\hline Transport equipment & $\mathrm{C} 30$ & $4.9 \%$ \\
\hline Other manufacturing & $\mathrm{C} 32$ & $2.5 \%$ \\
\hline $\begin{array}{l}\text { Electricity, gas, steam, water supply } \\
\text { Waste collection, treatment and disposal }\end{array}$ & $\begin{array}{c}\mathrm{D}, \mathrm{E} 36 \\
\mathrm{E} 38\end{array}$ & $2.6 \%$ \\
\hline Construction & $\mathrm{F}$ & $8.7 \%$ \\
\hline Wholesale and retail trade & G & $10.2 \%$ \\
\hline Transporting and storage & $\mathrm{H}$ & $3.5 \%$ \\
\hline $\begin{array}{l}\text { Accommodation, } \\
\text { Food and beverage service activities }\end{array}$ & $\begin{array}{l}\mathrm{I} 55, \\
\mathrm{I} 56\end{array}$ & $8.1 \%$ \\
\hline $\begin{array}{c}\text { Publishing } \\
\text { Programming and broadcasting activities }\end{array}$ & $\begin{array}{l}\mathrm{J} 58 \\
\mathrm{~J} 60\end{array}$ & $0.4 \%$ \\
\hline $\begin{array}{l}\text { Telecommunications, } \\
\text { Computer programming and related information services and activities }\end{array}$ & $\begin{array}{l}\mathrm{J} 61 \\
\mathrm{~J} 62 \\
\mathrm{~J} 63 \\
\end{array}$ & $6.5 \%$ \\
\hline Financial and insurance activities & $\mathrm{K}$ & $3.1 \%$ \\
\hline Professional, scientific and technical activities & M & $18.3 \%$ \\
\hline Public administration and defense; compulsory social security & $\mathrm{O}$ & $5.2 \%$ \\
\hline Education & $\mathrm{P}$ & $9.4 \%$ \\
\hline Human health and social work activities & Q & $3.3 \%$ \\
\hline Other activities & $\mathrm{S}, \mathrm{T}, \mathrm{U}$ & $4.5 \%$ \\
\hline All activities** & & $112.5 \%$ \\
\hline
\end{tabular}

* NACE: (Nomenclature of Economic Activities) is the European statistical classification of economic activities

**All is more than $100 \%$ because some respondents represent more activities

The questionnaire consists of groups of questions. These examine how prepared the companies are for emergencies, their response measures to the pandemic, HR actions taken in response to the pandemic, as well as their expectations for the future. 


\subsection{Major findings}

All research is worth as much as its results are useful in practice. For this reason, we not only describe the most important results of our questionnaire survey but also correlate them to observations and the conclusions drawn by scientific publications in numerous countries in the world. In this way, we can present how our own research results fit into the global perspective of the pandemic and HRM connection. This approach is essential because the pandemic itself and the resulting problems are also playing out on the global level, and the solution is also only possible by cooperation.

Willaim Petty was the first to use the expression of human capital, and he attempted to quantify its value monetarily (Varga, 1998). Nobel Prize winner T. W. Schultz determined that human knowledge is a defining factor in the workforce's economic role. This was created as a result of a long and expensive process, which greatly resembled physical capital investment processes (Schultz, 1961). Another Nobel Prize-winning scientist, Robert Fogel, determined that better life circumstances (nutrition, clothing, health) unequivocally play a role in economic growth (Fogel, 1994). Human capital is a basic tool for economic growth. The difference between the gross national product per capita per country is 10-30\% due to human capital (Hsieh \& Klenow, 2010). COVID-19 endangers this valuable tool. Despite this, at the time of the survey, only a few respondent organizations, $14 \%$, had a plan to manage extraordinary situations drafted before the virus, but 54 per cent drafted such a plan because of the crisis, and 10 per cent plans to develop a protocol. In the case of almost a fifth of respondents (19\%), the parent company drafted the plan for the pandemic, and 60 per cent of the respondent companies do this themselves. This result varies greatly from the results of the examination of higher education institutions in the present chapter. Only 3\% of Hungarian higher education institutions did not have such emergency plans in place, in the case of 84 percent, the parent institution had drafted the plan (Tóth \& Kálmán, 2020).

We also asked the questionnaire respondents about their expectations regarding macroeconomic changes. We foremost wished to gather data on the labour market and employment. Almost all respondents $(91,1 \%)$ expected unemployment rates to rise as a result of the coronavirus. More than half expected a significant increase (56,6\%), while approximately a third expected a mild increase (34,5\%). Domestic labour market indices have been improving over the past years, economic activity and employment have been increasing steadily since 2011 . In the final quarter of $2019,70 \%$ of the age group 15-64 were employed, which means a 15\% increase in the past ten years, while the unemployment rate decreased to $3,4(\mathrm{KSH}, 2020 \mathrm{a})$. According to the initial experiences during the coronavirus period, the majority of employers implemented the necessary measures in a short amount of time: no traveling, nor personal contact with clients, application of office rotation, greater emphasis on online communication. In some places working, rest, and vacation days were regrouped to ensure employees could stay home. A few employers agreed to issue employees vacation days. Others made agreements with their employees to the effect that they could miss work, but their salary will be lower. Those who were able to order employees to work from home. Within a short period of time, the home office arrangement became the everyday reality for tens of thousands of people, whilst previously only the upper-management had this opportunity. However, despite best efforts, the several-year positive trends in employment were disrupted, but the decrease in employment rates remained below $2 \%$. (Figure 4 ) 


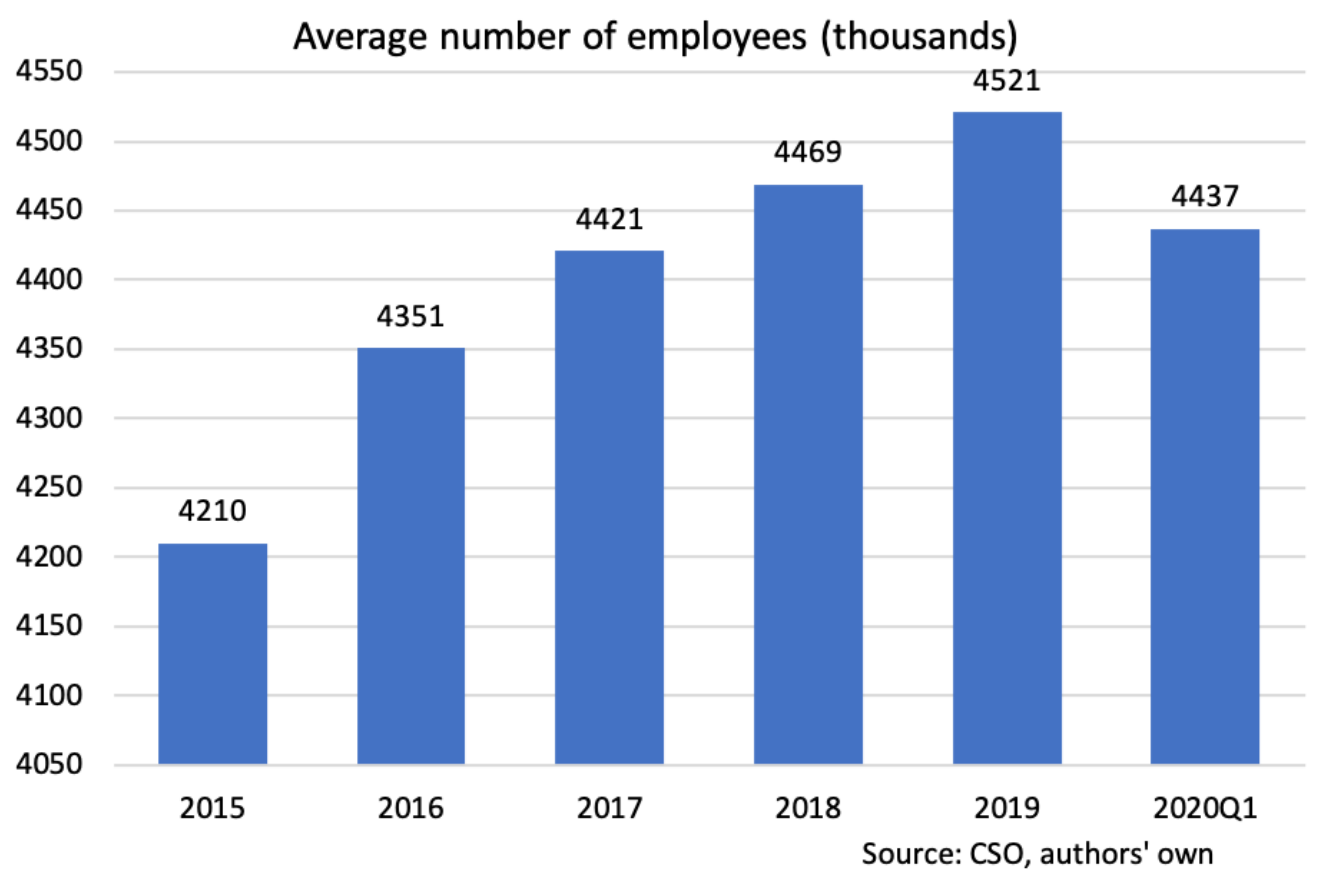

Figure 4. Average number of employees (thousands)

The number of those affected by collective redundancy peaked in June. At this time, nearly one hundred employers announced collective redundancy measures, which impacted over 7000 employees. In the beginning, redundancy affected mainly hotels, other hospitality businesses, passenger transport, the manufacturing sector, later accounting, auditing, and tax experts' activities (KSH, 2020c). The same trends are represented in foreign literature: Hotel services (Gursoy \& Chi, 2020), restaurants (Kashif et al., 2020), passenger transportation (Tirachini \& Cats, 2020), as well as the manufacturing of electronic devices (Harris et al., 2020), and later in the case of accounting, auditing, and tax expert activities (Albitar et al., 2020) as well. The emphasis on commerce moved to online spaces, and many salespeople and cashier jobs became redundant both in Hungary and on the international labour market (Kim, 2020; Poór et al., 2020). Commercial accommodations, however, experienced the greatest deficit. In April 2020, they reported a loss of $99 \%$ of overnight stays and a $97 \%$ decrease in revenue.

The pandemic can unequivocally explain the decline. Compared to estimates calculated from the time-series data, the actual values are significantly lower. Regarding the individual sectors, employment decreased foremost in the hospitality and service provision sector, and industrial employment experienced little to no change. The most insignificant decrease was in the construction industry. The changes to the industrial sector are almost exclusively due to the effects of the pandemic, but in the case of the hospitality industry, for instance, the seasonal nature of these businesses must also be taken into account, as analyzed in the professional literature (Arasli et al., 2020). International observations are congruent with our own. We examined the period between March to May of 2020 in our questionnaire survey. The first quarter of the coronavirus crisis caused some redundancy in barely one-third of organizations $(32,2 \%)$, and within this third, only $9,4 \%$ experienced a significant redundancy of over 20 per cent of the workforce. (Figure 5) 


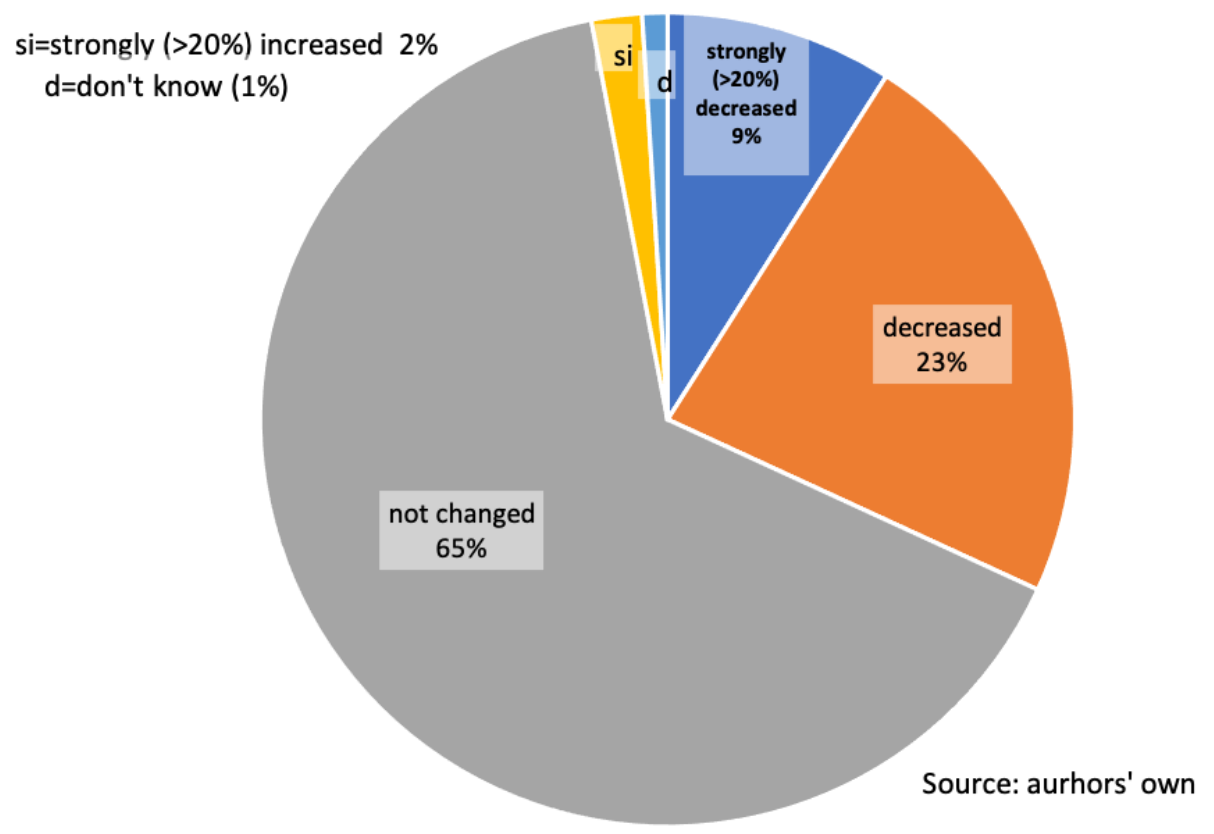

Figure 5. Workforce trends 2020 (March - May)

The numbers of those affected by collective redundancy may increase later when further businesses are forced to downsize due to the experienced losses, if the pandemic situation becomes more severe, or if said businesses cannot survive the prolonged crisis. This is evidenced by the fact that $45 \%$ of downsizing organizations stated that they had also terminated the given positions even in the pandemic's initial stage. Simultaneously, expansion or the creation of new positions happened in far fewer areas than before, with the majority of these being IT positions related to e-commerce (Kwan, 2020; Lesi, 2020). In summary, for every six terminated positions, one new position was created, and for every five redundancies, there was one expansion. Taking into account these ratios, many more people lost their jobs than those who found new jobs. In the interest of ameliorating the problems, the government reacted with several measures. Among other things, the presently effective government decision, based on which during the coronavirus situation, even those who would otherwise be able to find work on the labour market can take part in the public work program, brought many changes. The limitations applicable to those with vocational qualifications also ceased. The amendment gives - a more comprehensive range of those who have lost their jobs due to the pandemic - the opportunity to participate in the public work program. All this is in accordance with the aims of the government that if after the three months of unemployment support are over, and the person still cannot find work on the labour market, the state will provide them with a job (Portfolio, 2020).

The complex package of measures known as the economic protection action plan, which provided further financial and legal support to employers and employees, meant further assistance in the interest of preventing the suspension of the economy and aiding recovery as soon as possible. The governmental measures included several allowances, with the Ministry of Finance experts and the Central Bank of Hungary playing the main role in drafting these packages. Among these are the wage subsidies, which have saved many jobs. Freezing the payment of contributions has done much to unburden employers, as have the long extensions of the deadlines for paying company tax. The opportunity for taking out soft loans was also made possible. The government regulation that allowed for the moratorium on loan repayment instalments eased many families' financial burden. These measures were necessary also because our greater community, the EU, has not, to this date, drafted a uniform policy for managing the effects of COVID-19. Thus, it is no coincidence that based on the 
EU COVID Opinion Survey, in 20 of the 27 member states, dissatisfaction with the implemented measures is at $40 \%$ (Schulmeister, 2020).

The OECD survey (OECD, 2020) summarises the measures taken to support small and midsize businesses characteristic of the individual member states; the measures are grouped into four categories. The table below compares the Indian and Hungarian small to midsize business sectors (Table 5).

Table 5 .

Supporting measures for SMEs in India and Hungary (Source: OECD, 2020 - edited by authors)

\begin{tabular}{|c|c|c|c|}
\hline & & India & Hungary \\
\hline \multirow{3}{*}{ Labour } & (partial) redundancies & & + \\
\hline & wage subsidies & + & + \\
\hline & self-employed & & + \\
\hline \multirow{5}{*}{ Deferral } & income/corporate tax & + & + \\
\hline & value-added tax (VAT) & & \\
\hline & social security and pension & & + \\
\hline & rent/utilities/local tax & & + \\
\hline & debt moratorium & & + \\
\hline \multirow{3}{*}{ Financial instruments } & loan guarantees & & + \\
\hline & direct lending to SMEs & + & + \\
\hline & grants and subsidies & & \\
\hline \multirow{4}{*}{ Structural policies } & new markets & & \\
\hline & teleworking/digitalization & & \\
\hline & innovation & & \\
\hline & training and redeployment & & \\
\hline
\end{tabular}

We need the following background information to interpret the table: the most commonly used tools of responding to the outbreak of the pandemic in OECD member states were the postponement of income and profit taxes, credit guarantees, and direct loans provided too small to midsize businesses, as well as wage subsidies. This is according to the World Bank's recommended measures for the support of small and midsize businesses, which points to the fact that the means for supporting small to midsize businesses worldwide are related to tax financing (loans and guarantees), employment subsidies, and taxation. Structural policies are applied less frequently, mainly focusing on working remotely and digitalization, however, over time, the number of countries implementing such policies has increased. The support, debt moratorium, and the unique measures applying to the self-employed are very different from country to country. The OECD defines three characteristic areas of support in India, while in Hungary, there are nine. At first glance, it may seem odd that restructuring measures are not present in the case of either country. The explanation behind this is that these measures, with a few exceptions, such as online learning, were implemented not by the state but by the businesses at their own discretion.

Naturally, the companies themselves also took the responsive steps by which they hoped to maintain their employees. Among these were the issuing mentioned above of vacation time, restructuring 
working hours, transitioning to a home office, and moving education completely into digital spaces (emergency remote teaching - ERT). According to our questionnaire, 31 per cent of companies experienced a period of suspended operation, whether longer or shorter, the temporal spectrum of these was quite wide-ranging from a few days to closing down for over two months. The most expected duration was from 6 to 10 weeks, a third of the companies forced to close down did so for such a duration. Issuing vacation time to employees was less common than expected. 14\% of questionnaire respondents were forced to take their annual vacation, while only 4.5 were forced to go on unpaid leave. Employees consider the burdens placed on the family (24\%), work-private life conflicts (23\%), and the decline in their income to be the most important issues (Schulmeister, 2020). The union's statistically average citizen is foremost concerned with financial matters: decreased income, being forced to use up their savings, and unemployment. The general countermeasures to the pandemic are summarised in (Figure 6).

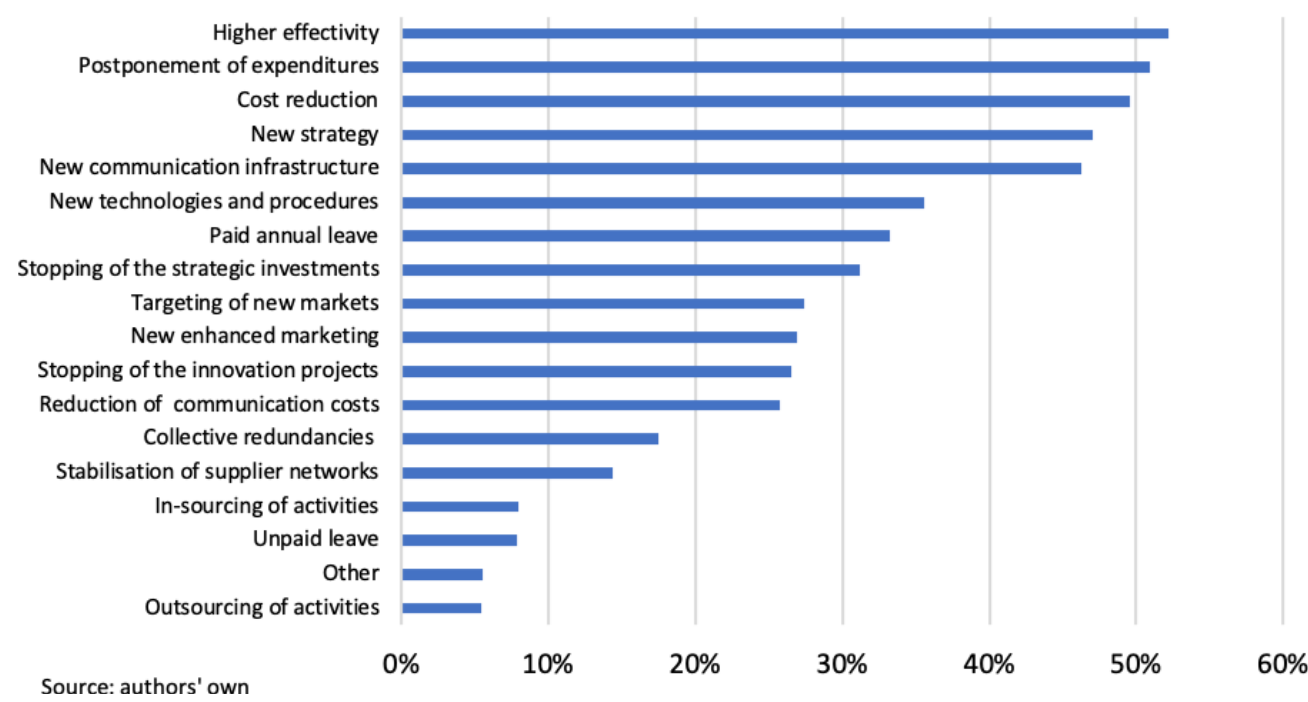

Figure 6. General counter-measures

The most frequently applied measures taken by the companies we examined: increasing organizational efficacy, general budget cuts, postponing acquisitions and expenses, and strategic restructuring. Even though it is not among the first four, communication tools' development comes in at a close fifth. Simultaneously, almost no one chose outsourcing, which is a logical decision during a global pandemic when economic and healthcare prospects are not better in other countries either. Company leaders implemented similar measures in these countries as well (Nyanga, 2020). If possible, working from home was ordered, and employees-maintained contact with the company and clients online. Working from home contributed to decreased costs, utility costs decreased, as did travel support. Based on the answers we received via our survey, the process that led to the crisis is readily apparent. The lockdown measures due to the pandemic had negative effects on consumption, partly due to decreased shopping opportunities and due to the lack of income because of the necessary closing down of workplaces. The decrease in demand affected not only the domestic market but foreign markets as well, with the determining factor in the latter being mainly the interruption of the supply chain. The decreased demand further expedited the economic decline (already operating on standby) and led to the crisis. (Figure 7) 


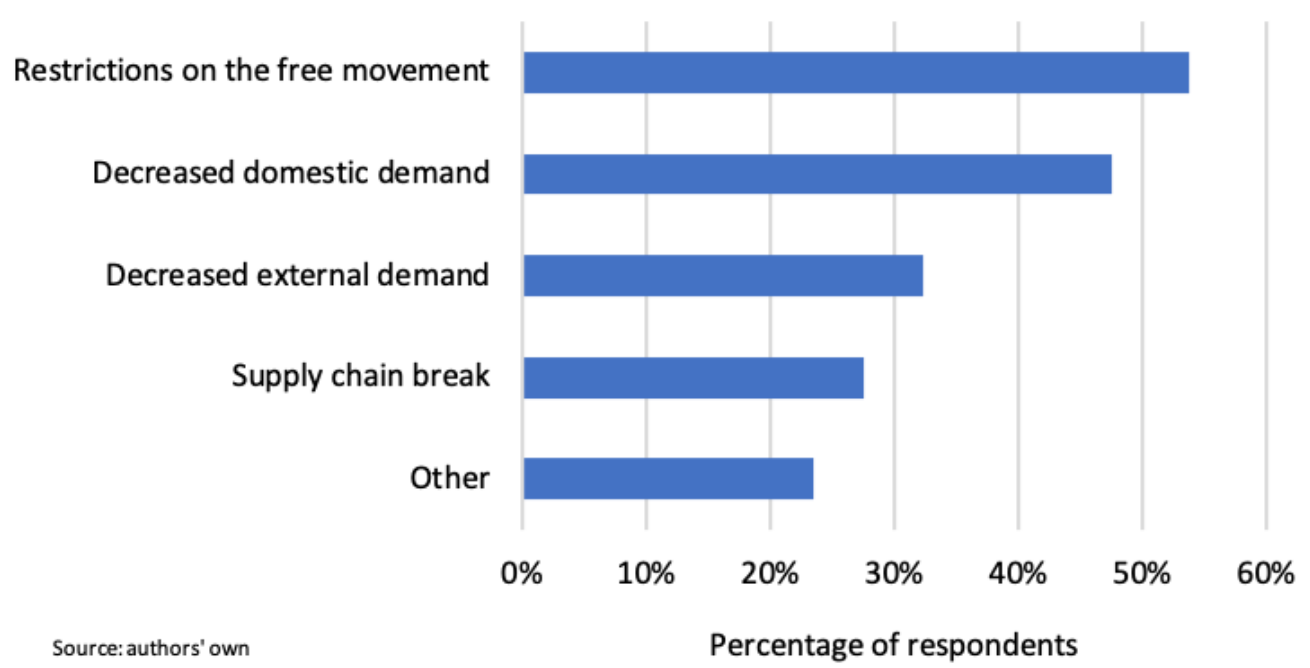

Figure 7. Economics stress factors

For companies, besides the changes performed within their purview, there has been an opportunity to take advantage of numerous state-developed economic protection measures. These primarily aimed to satisfy the need for financial resources. Based on our questionnaire results, the wage subsidies represented the greatest assistance, which was used by nearly one quarter (24\%) of the respondents. Considering the fact that a majority of Hungarian enterprises use credit-covered resources for their operation, it is not surprising that the second most applied solution was the credit moratorium; this was used by $11 \%$ of the companies that participated in our research to improve their resource position. Other financial easing measures, such as the rent freeze, were used by considerably fewer enterprises, only $3.5 \%$. However, it appears surprising that despite the crisis, the same proportion took loans as a solution. In this the not insignificant fact certainly played a motivating role that although due to the difficult situation, banks reduced their loaning activities, the state loan and loan guarantee programs are effectively supporting enterprises in obtaining resources: in the case of SME's, on top of the NHP Hajrá (Rush) the Széchenyi Card program represents the leading financing resource (Drabancz et al., 2020). The loan payback moratorium on long term bank loans affects over 33 thousand enterprises, but since the moratorium includes short term bank loans as well, this number may be several times higher; on the nationwide average, the proportion of loans is $16.3 \%$. This proportion is significantly higher in some sectors: thus in the case of agriculture, it is $69.5 \%$, in the commercial and automotive repair sectors it is $53 \%$, in the case of accommodation and hospitality it is $43.1 \%$, and $40 \%$ in the area of the processing industry, meaning that the effect of the moratorium will be more intense there (Pénzcentrum, 2020). Further considerable easing was achieved by tax and contribution payment discount programs, primarily by postponing the payment of the corporate tax and local business taxes from May to September. Decisions have been made regarding numerous other sector-specific discounts. Based on Government Decree No 47/2020 (18 March), in the most impacted sectors (tourism, hospitality, entertainment, performance art, event organization and sports services), the taxpayers will be exempted from the social contribution, the vocational training contribution and the rehabilitation contribution in a time proportional manner for the months of March, April, May and June 2020 (MKO, 2020). This represented significant assistance for more than two-thirds of companies in acquiring the resources needed for operations. As a result, in the first quarter of 2020, SME's investment performance that comprises the Hungarian economy's essence still grew compared to the previous period, though to a much lower extent, by $4 \%(\mathrm{KSH}, 2020 \mathrm{a})$. In this same period, as a consequence of a drop in budgetary and other investments, the national economy's total investment 
volume showed a $1.8 \%$ decline. At the same time, the number of newly registered SME's was reduced from month to month. The growth we have seen compared to April 2019 was essentially and mostly caused by a nearly $6 \%$ increase in the number of private entrepreneurs. However, at least partly can be explained by the increase of those who were forced to become private entrepreneurs due to the decline in employment positions. The pandemic's effect can be seen more profoundly in the second quarter statistics (KSH, 2020b). The GDP took a 13\% nosedive compared to the same period in the previous year, the decline in the annualized index was 46.8\%. In the August-October 2020 period, the average number of employed was 38 thousand persons, less than a year earlier (KSH, 2020a). We separately examined the role and challenges of HR during the coronavirus pandemic. As the first and most important question, we asked if Hungarian enterprises even have organized HR divisions or at least relevant activities, considering that an overwhelming majority of them are SME's. Figure 8. shows our results.

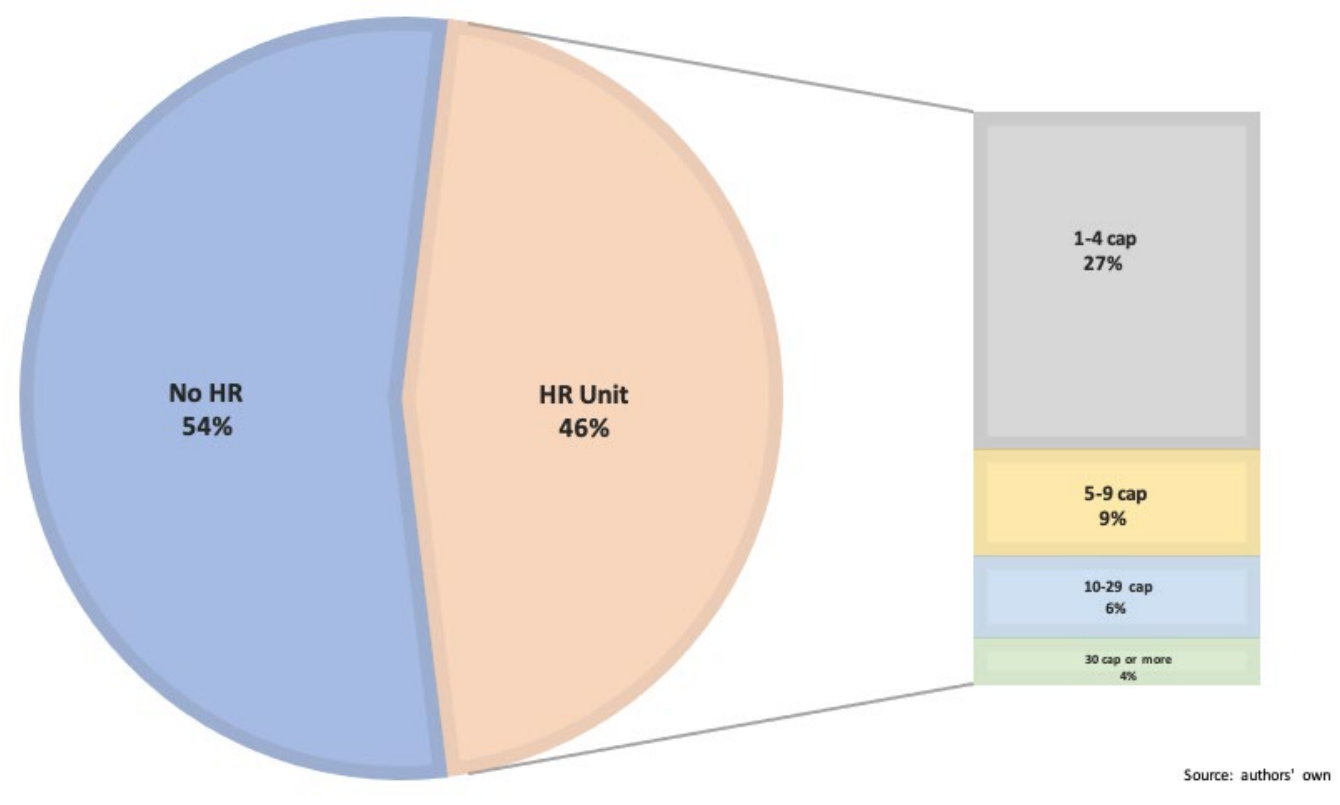

Figure 8. HR units by firms

It is not surprising that a majority of SME's do not establish a separate HR division because of their size, and even at the companies that have such divisions, the number of employees involved in working there is mostly low. Only $4 \%$ of the respondent companies have HR divisions employing 30 or more staff members.

The COVID-19 pandemic and the government measures taken in response to it forced HR management to react quickly as well. Measures had to be taken fast that under usual circumstances are generally possible to plan in advance. Our respondents characteristically indicated three HR activities that the examined companies performed as an immediate reaction: ordering/allowing home office work, the introduction of new workplace safety and health protection measures and the workforce freeze, to which as a fourth component they attached assistance in solving the social problems of their employees. Wage reductions have been very rare, wage freezes were somewhat more frequent. Since the pandemic caused significant changes in the world of work, we were also curious about possible changes in the internal expectations regarding the HR area's efficiency in our survey. $52 \%$ of the respondents who have a separate HR division increased their expectations in this area. According to $61 \%$ of the respondents, those who work in HR have to perform more tasks than before the virus crisis's appearance. Numerous factors may explain the increase in the volume of 
tasks: work from home, the practical adaptation of temporary work rules, or increased HR administration. The strategic role and significance of human resource planning had been recognized by $63 \%$ of the companies that participated in the research, and $54 \%$ of companies took measures to retain their key staff, their professional employees with outstanding knowledge. One-third of the respondents strongly hope that the unique and challenging to copy knowledge and expertise in their organization may provide a way out of the crisis. In international comparison, the situation is very similar (Lewis, 2020). Not only are HR professionals concerned about employees' health and wellbeing during the pandemic, but they are also under the strain of processing the paperwork and providing solace to the millions of workers who have been laid off or furloughed. For employees still, on the job, HR managers are trying to keep their workers productive, motivated, engaged and connected - all factors that are moving targets in the new normal. One of the long term effects of the pandemic is expected to be an increase in the proportion of remote work since, according to the statistics of Flexjobs (Hering, 2020), this form of employment showed dynamic growth even before the pandemic (Figure 9).
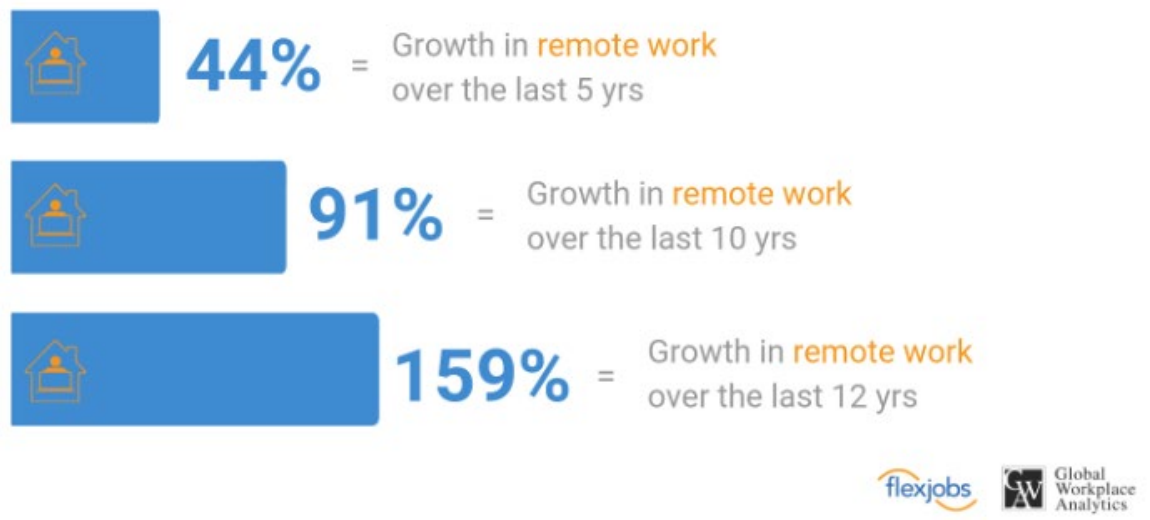

Figure 9. Trends in remote work growth

\section{Conclusions}

2020 will be the year of the coronavirus in history books. The epidemic caused by the virus became global and has led to the deaths of millions in the nearly one year since its emergence. Every aspect of our lives has changed, our social relationships, recreational activities, work and the entirety of the economy. The crisis has resulted in a global recession, which according to the 2021 estimates of the World Bank, will be more severe than the Great Depression of 1929-1933 in its economic impact. To solve the situation, trilateral cooperation is necessary: a joint effort of employees, employers and the state. Our research examined the possibilities of this joint effort, focusing primarily on employers' aspect and within that on HRM.

We conducted the first phase of our online research between 15 June and 31 July 2020. In this period, relying on answers to questionnaires returned by 508 respondents (companies, institutions, and nonprofits), the picture of the pandemic's first wave can be outlined. Our research primarily explored HR's role and tasks based on the pandemic's first wave experiences. In this area, among the challenges related to the virus situation, the greatest ones were effective internal communication, information provision, and maintaining contact for organizations. These were followed by workforce retention difficulties, the introduction/operation of remote work, and compliance with health protection and hygiene regulations. The measures primarily focused on new workplace safety and health protection activities, the development and management of working from home (home office), the preparation/revision of recruitment/substitution plans, and assistance in employees' social problems. 
The coronavirus pandemic disrupted organizations and caused human resources managers to think differently about their role as they adjust to social distancing practices and a new work environment that they may never have imagined. To prevent the coronavirus spread, companies have switched to a remote work model at a rate and scale they have never experienced. As face-to-face collaboration is replaced with email and videoconferencing, HR managers have to do complex work under challenging circumstances. Ensuring communication became the primary task. Strategies had to be developed whereby talented employees can be retained, who play key roles in the company's performance. For this reason, the contact establishment ability of HR will continue to be a defining factor of this activity in the future. Raising the satisfaction of employees to a sufficient level has become an essential task. Employees must feel that their company takes care of them and their problems, while it provides all technical and other types of support to perform their work more efficiently.

Claudine Naughton, chief people officer at Activision Blizzard, summarised the expected future of HRM (Lewis, 2020): "While previous tactics and strategies will continue to be a part of HR managers' toolkit to manage employees efficiently, Activision Blizzard's Naughton sees a bigger shift taking place in the wake of the coronavirus that will fundamentally change the role of HR professionals. What has changed the most for HR professionals and the role that they will play moving forward is that, in our world, the focus tended to be on pay. Now we believe health and wellness benefits are going to be a game-changer. Our entire health care system, particularly in the U.S., will evolve with the private-sector and the public-sector communities working to fix what seems to be a relatively broken system. That is going to change the role of HR professionals in the foreseeable future."

The currently presented results are based on the compilation of responses in the first phase of our research. But the work is continuing forward. The second research report processes the period between 1 August and 15 November 2020. In this phase, the number of respondents exceeded one thousand, and an increasing number of people fill in the questionnaire in neighbouring countries, which are adapted to the economic conditions there and are translated into English or the language of the specific country. With this, in the future, it will become possible to compile a comparative study including one where the analysis explores not just development in time but will extend to several countries, the work connected to which has already commenced. Meanwhile, the research has entered its third phase. At the conclusion of the chapter, at the beginning of December 2020, the first vaccination campaigns have started in the United Kingdom and Russia, and several vaccines are currently undergoing licensing. We strongly hope that the conclusion of the third phase of our research will coincide with the end of the pandemic.

Finally, as closing the chapter, the authors would like to say thanks for the opportunity to participate as the representatives of their countries in the joint work of writing this book.

\section{References}

Albitar, K., Gerged, A. M., Kikhia, H., \& Hussainey, K. (2020). Auditing in times of social distancing: The effect of COVID-19 on auditing quality. International Journal of Accounting \& Information Management, ahead-of-print(ahead-of-print). https://doi.org/10.1108/IJAIM-08-2020-0128

Arasli, H., Altinay, L., \& Arici, H. E. (2020). Seasonal employee leadership in the hospitality industry: A scale development. International Journal of Contemporary Hospitality Management, 32(6), 2195-2215. https://doi.org/10.1108/IJCHM-05-2019-0508

Balogh G., Király Z., Kópházi A., Kun A. I., \& Poór J. (2020). Objectives, methods and first experiences of the Hungarian national KoronaHR research project in Hungarian.New Hungarian Labor Review (Új Munkaügyi Szemle), 14), 2-7. 
Berend T. I. (1999).On a diversion road. Central and Eastern Europe. 1944-1990. (In Hungarian)Vince Publishing House.

Bod, A-P. (2014). Why there was no Marhall aid after 1990. Hungarian Review, 5(5). http://www.hungarianreview.com/article/20140919_why_there_was_no_marshall_aid_after_1990. (Accessed: April 6, 2021)

Caligiuri, P., De Cieri, H., Minbaeva, D., Verbeke, A., \& Zimmermann, A. (2020). International HRM insights for navigating the COVID-19 pandemic: Implications for future research and practice. Journal of International Business Studies, 51(5), 697-713. https://doi.org/10.1057/s41267-020-00335-9

Carare, A. (2009). IMF Survey: Hungary Succeeds in Early Return to Market Financing. IMF News, https://www.imf.org/en/News/Articles/2015/09/28/04/53/socar073009b. (Accessed: 8 April, 2021).

Drabancz, Á., Hegedüs, S., Marosi, A., \& Szabó, B. (2020). Loans 2020 (In Hungarian) (No. 202009). MNB. https://www.mnb.hu/letoltes/hitelezesi-folyamatok-2020-szeptember-hu.pdf

Eurostat (2020). Job vacancy statistics. https://ec.europa.eu/eurostat/statistics-explained/index. php/Job_vacancy_statistics. (Accessed: 2 April, 2020)

Eurosat (2021). Unemployment statistics. https://ec.europa.eu/eurostat/statistics-explained/index.php /Unemployment_statistics (accessed: April 8, 2021).

Fogel, R. W. (1994). Economic Growth, Population Theory, and Physiology: The Bearing of Long-Term Processes on the Making of Economic Policy. The American Economic Review, 84(3), 369-395. https://doi.org/10.3386/w4638

Gigauri, I. (2020). Influence of Covid-19 Crisis on Human Resource Management and Companies' Response: The Expert Study. International Journal Of Management Science And Business Administration, 6(6), 1524. https://doi.org/10.18775/ijmsba.1849-5664-5419.2014.66.1002

Gulyás L., \& Turcsányi E. (2017). Development of human resource management functions Part 1 (In Hungarian). Central European Review (Közép Európai Közlemények), 10(3), 195-205.

Gursoy, D., \& Chi, C. G. (2020). Effects of COVID-19 pandemic on hospitality industry: Review of the current situations and a research agenda. Journal of Hospitality Marketing \& Management, 29(5), 527-529. https://doi.org/10.1080/19368623.2020.1788231

Harris, J., Sunley, P., Evenhuis, E., Martin, R., Pike, A., \& Harris, R. (2020). The Covid-19 crisis and manufacturing: How should national and local industrial strategies respond? Local Economy: The Journal of the Local Economy Policy Unit, 35(4), 403-415. https://doi.org/10.1177/0269094220953528

Hering, B. B. (2020). Remote Work Statistics: Shifting Norms and Expectations. https://www.flexjobs.com/blog/post/remote-work-statistics/

Hofstede, G., Hofstede, G. J., \& Minkov, M. (2010). Cultures and Organizations: Software of the Mind (3rd ed.). McGraw-Hill Education - Europe. https://www.bookdepository.com/Cultures-OrganizationsSoftware-Mind-Third-Edition-Geert-Hofstede/9780071664189

Hsieh, C.-T., \& Klenow, P. J. (2010). Development Accounting. American Economic Journal: Macroeconomics, 2(1), 207-223. https://doi.org/10.1257/mac.2.1.207

Investment Climate Statements: Hungary (2019) https://www.state.gov/reports/2019-investment-climatestatements/Hungary/(accessed: 6 April, 2021)

Jarjabka, Á. (2014). Company cultures in international environment. 96-118. In. Blahó, A., Czakó, Zs \& Poór, J. International Management (In Hungarian) Budapest: Academic Publishing House.

Karoliny, M., \& Poór, J. (2019). Human Resource Management Manual. (In Hungarian). MERSZ. https://mersz.hu/hivatkozas/YOV1682_221\#YOV1682_221

Karoliny, Zs., Farkas, F., \& Poór, J. (2009). In focus, Hungarian and Central-Eastern European characteristics of human resource management - An international comparative survey. Journal of East European Management Studies, 14(1), 9-47. https://doi.org/10.5771/0949-6181-2009-1-9

Kashif, M., Rehman, A.-U., \& Javed, K. (2020). Restaurants_and_Covid_19_85-Article Text-223-1-1020200526.pdf. International Journal of Medical Science in Clinical Research and Review, 3(3), 281-289.

Kim. (2020). The Impact of COVID-19 on Consumers: Preparing for Digital Sales-IEEE Journals \& Magazine. IEEE Engineering Management Review, 48(3), 212-218. https://doi.org/10.1109/ EMR.2020.2990115 
Kornai, J. (1992). The Socialist System: The Political Economy of Communism. Princeton University Press. https://www.amazon.com/Socialist-System-Political-Economy-Communism-dp-0691042985/dp/069104 2985/ref=mt_other?_encoding $=\mathrm{UTF} 8 \& \mathrm{me}=$ \&qid=

KSH. (2020a). Hungary-2020 Q1 (In Hungarian). http:/www.ksh.hu/docs/hun/xftp/idoszaki/mone/ 20201/index.html

KSH. (2019). The main elements of the monthly labor cost in HUF in Hungarian (In Hungarian) https://www.ksh.hu/docs/hun/xstadat/xstadat_eves/i_qli053a.html

KSH. (2020a). Employment data, in Hungarian (In Hungarian) https://www.ksh.hu/docs/hun/xftp /gyor/fog/fog 2010. html

KSH. (2020b). Hungary-2020 Q2 in Hungarian. (In Hungarian) https://www.ksh.hu/docs/hun/xftp /gyor/gdp/gdp2009.html

KSH. (2020c). STADAT - 2.1.7.2. (2008-2019). https://www.ksh.hu/docs/hun/xstadat/xstadat_eves/ i_qlf005a.html

Kwan, S. H. (2020). Market Assessment of COVID-19. FRBSF Economic Letter, 2020(14), 1-5.

Lesi, H. (2020). The Influence of Information Technology Covid-19 Plague Against Financial Statements and Business Practices. Ilomata International Journal of Tax \& Accounting, 1(3), 10.

Lewis, P.C. (2005). How the East was won. New York: Palgrave Macmillan.

Lewis, N. (2020). HR Managers Rethink Their Role During the Coronavirus Pandemic. https://www.shrm.org /hr-today/news/hr-news/pages/hr-managers-rethink-their-work-coronavirus-pandemic.aspx

MKO. (2020). Hungarian Public Online Review (In Hungarian) http://www.kozlonyok.hu/nkonline /index.php?menuindex $=200$ \&pageindex $=$ kozltart\&ev $=2020 \&$ szam $=47$

Nádor, É. (1996). Japanese Investors in Hungary—(In Hungarian) Marketing \& Menedzsment, 30(4), 36-41.

Nagy, A. (2015). What does HR want? (In Hungarian) https://www.hrportal.hu/c/mire-vagyik-a-hr-es20150609.html

Nyanga, T. (2020). Reactions of small to medium enterprises in Masvingo, Zimbabwe to COVID 19: Implications on productivity. Business Excellence and Management, 10(1), 22-32.

OECD. (2020). Coronavirus (COVID-19): SME Policy Responses (p. 169) [Global Report]. https://read.oecdilibrary.org/view/?ref=119_119680-di6h3qgi4x\&title=Covid-19_SME_Policy_Responses

Pénzcentrum. (2020). The repayment moratorium helps the most in these sectors: It can save 33,000 companies (In Hungarian) [Pénzcentrum]. https://www.penzcentrum.hu/hitel/ezekben-az-agazatokban-segit-legtobbet -a-torlesztesi-moratorium-33-ezer-ceget-menthet-meg.1091018.html

Poór, J., \& al. (2020). Coronavirus Crisis Challenges and HR Responses Hungary 2020. (In Hungaria). Szent István Egyetem Menedzsment és HR Kutató Központ.

Poór, J., Engle D., A., Blstakova, J. \& Joniaková, Z. (2018). Internalisation of Human Resource Management in Central and Eastern Europe. New York: Nova Publishing.

Poór J., \& Roberson M. (2003). Global development: The effectiveness of human resource management (HRM) by Hungarian companies at the beginning of the new millennium in Hungarian). Budapest Management Journal (Vezetéstudomány), 34(1), 13-19.

Poór, Karoliny, Z., Alas, R., \& Kirilova Vatchkova, E. (2011). Comparative international human resource management (CIHRM) in the light of the Cranet Regional Research Survey in Transitional Economies. Employee Relations, 33(4), 428-443. https://doi.org/10.1108/01425451111142710

Portfolio. (2020). Government decision: Changes in public work (In Hungarian). https://www.portfolio. hu/gazdasag/20200516/itt-a-kormany-dontese-nagy-valtozas-jon-a-kozmunkaban-432224

Prime Minister's Office. (2020). The government declares a state of emergenc. (In Hungarian). https://20152019.kormany.hu/hu/miniszterelnokseg/videok/veszelyhelyzetet-hirdet-a-kormany

Schulmeister, P. (2020). EU Covid Opinion Survey. European Parliament.

Schultz, T. W. (1961). Investment in human capital. The American Economic Review, 51(1), 1-17.

Szegö, P. (2015). Financial experts reflect on the Bokros package of 1995. https://budapestbeacon.com /financial-experts-reflect-on-the-bokros-package-of-1995/ (Accessed: 8 April, 2021)

Tirachini, A., \& Cats, O. (2020). COVID-19 and Public Transportation: Current Assessment, Prospects, and Research Needs. Journal of Public Transportation, 22(1). https://doi.org/10.5038/2375-0901.22.1.1 
Torrington, D., \& Hall, L. (1987). Personnel Management: A New Approach. Prentice-Hall. https://books.google.hu/books/about/Personnel_Management.html?id=WmZoQgAACAAJ\&redir_esc=y

Tóth, A., \& Kálmán, B. (2020). Effects of COVID-19 on higher education in Hungarian [in press]. Komárno: J.Selye University.

Varga, J. (1998). Oktatásgazdaságtan. http://www.kszemle.hu/kiadvany/Varga_-_Oktatasgazdasagtan/ch01.html

WHO - PLC. (2020). Listings of WHO's response to COVID-19. https://www.who.int/news/item/29-06-2020covidtimeline

Wolf, J. \& Poór J. (1990). A socioeconomic Note on Hungary. 1014-1038. In. Thomas, L.T.\& Hungar, J.D. Strategic Management and Bussiness Policy. Reading Massachusets: Addison Wisley Publishing House.

\section{Proud Pen}

(C) 2021 The Author(s). Licensee Proud Pen Limited. This chapter is distributed under the terms of the Creative Commons Attribution License (https://creativecommons.org/licenses/by/4.0/), which permits unrestricted use, distribution, and reproduction in any medium, provided the original work is properly cited.

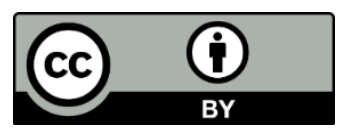

